\title{
PENGUJIAN KERAPATAN DAN KADAR AIR SERTA PENGUJIAN KOEFISIEN ABSORBSI UNTUK MENGETAHUI PENGARUH VARIASI KETEBALAN DAN FREKUENSI TERHADAP PAPAN AKUSTIK BERBAHAN DASAR DAUN PANDAN DURI (PANDANUS TECTORIUS)
}

\author{
Hasniati Hasan $^{1}$, Sahara $^{1}$, dan Sri Zelviani ${ }^{1}$ \\ ${ }^{1}$ Jurusan Fisika, Fakultas Sains dan Teknologi, Universitas Islam Negeri Alauddin Makassar \\ email: hasniatihasan97@gmail.com, rarafis_uin@yahoo.co.id, sri.zelviani@uin-alauddin.ac.id
}

\begin{abstract}
This study aims to determine the physical properties associated with the density and moisture content of acoustic boards made from thorny pandan leaves and to determine the effect of thickness and frequency variations on the absorption coefficient of acoustic sound based on thorny pandan leaves. The method used in this research is to make an acoustic board with two types of samples, namely mash samples and blender samples with thicknesses of 0.7 $\mathrm{cm}, 1.0 \mathrm{~cm}, 1.2 \mathrm{~cm}$ and $1.5 \mathrm{~cm}$, as well as measuring the values of density, moisture content absorption coefficient with thickness and frequency variations. The frequency values used are $125 \mathrm{~Hz}, 250 \mathrm{~Hz}, 500 \mathrm{~Hz}, 1000 \mathrm{~Hz}, 2000 \mathrm{~Hz}$ and $4000 \mathrm{~Hz}$. Based on the results of the research, the absorption coefficient value is inversely proportional to the thickness, where the thicker a material, the smaller the absorption coefficient, the good absorption coefficient value at the frequency of $4000 \mathrm{~Hz}$ at a thickness of $1.0 \mathrm{~cm}$ for blender samples and mash samples, namely 0.199 and 0.288 .
\end{abstract}

Keywords: thorny pandan leaves, absorption coefficient, frequency, density, water content.

\section{PENDAHULUAN}

Makassar merupakan salah satu kota terbesar di Sulawesi Selatan, berdasarkan Badan Pusat Statistik (BPS) jumlah penduduk Sulawesi Selatan paling banyak berada di Makassar dengan jumlah penduduknya mencapai 1,5 juta jiwa, banyaknya jumlah penduduk menyebabkan semakin banyak ragam aktivitas yang dilakukan oleh setiap masyarakat yang dapat menimbulkan kebisingan.

Kebisingan merupakan suatu bunyi atau suara yang tidak dikehendaki oleh seseorang, sehingga sekecil atau selembut apapun bunyi atau suara yang terdengar jika hal tersebut membuat seseorang yang mendengarnya merasa tidak nyaman, maka suara atau bunyi tersebut dapat dikatakan sebagai suatu kebisingan. Kerusakan pada indera pendengaran (hilangnya pendengaran secara sementara, telinga berdengung, kehilangan pendengaran secara permanen), selain pengaruh bising terhadap sistem pendengaran, bising dapat pula mengganggu konsentrasi, meningkatnya kelelahan, dapat menyebabkan gangguan hormonal, sistem syaraf dan juga dapat merusak metabolisme (Gabriel, 1996).

Banyaknya masalah yang timbul akibat dari kebisingan, maka diperlukan suatu bahan yang dapat dijadikan sebagai papan akustik yang baik dalam meredam suara, namun dengan bahan yang mudah didapatkan dan dengan 
harga yang terjangkau. Penelitian yang dilakukan oleh Akbar (2017) pembuatan papan akustik dari bahan dasar limbah kulit jagung dengan perekat lem fox, nilai koefisien absorbsi yaitu $>0,15$. Penelitian yang dilakukan oleh Kusuma (2012) yaitu menggunakan bahan dasar kayu segon, nilai koefisien yang diperoleh yaitu rata-rata 0,3. Penelitian yang dilakukan oleh Karlinasari, dkk (2011), menggunakan papan wol dari beberapa kayu cepat tumbuh sebagai panel absorbsi atau penyerap suara, diperoleh koefisien absorbsi yaitu 0,6. Penelitian oleh Ulfayanti (2016) dengan menggunakan bahan sandwich kertas koran dan gabus dengan perekat sagu, diperoleh nilai koefisien absorbsi yaitu 0,1 . Penelitian yang dilakukan oleh Suhaemin, dkk (2013), menggunakan bahan dasar serbuk kayu kelapa dalam pembuatan papan partikel dan diperoleh nilai koefisien yaitu 0,1 .

Daun pandan duri (pandanus tectorius) merupakan salah satu tumbuhan yang banyak tumbuh di daerah pesisir pantai, tumbuhan ini sangat terkenal dikalangan masyarakat karena daun pandan duri banyak dijadikan sebagai bahan anyaman, seperti membuat tikar, topi, tas dan beberapa kerajinan tangan lainnya. Daun pandan duri merupakan tanaman berpori dengan kandungan kimia yaitu lignin (18-22\%), selulosa (83-88\%) dan holoselulosa (37-76 \%). Menurut Je Audibel (2009) dalam Ulfayanti (2016) menyatakan bahwa ketika suatu bahan memiliki kandungan selulosa diatas $40 \%$, maka bahan tersebut baik digunakan sebagai penyerap bunyi karena memiliki koefisien serap hingga 0,9.

Koefisien absorbsi suara ( $\alpha$ ) merupakan perbandingan antara energi suara yang diserap oleh bahan tersebut terhadap energi suara yang menuju permukaan bahan (Sarwono, 2009 dalam Kusuma, 2012). Semakin besar nilai $\alpha$ maka bahan tersebut akan semakin baik digunakan sebagai peredam suara. Nilai a berkisar dari 0 sampai 1 . Jika nilai a bernilai 0 , artinya tidak ada bunyi yang diserap, sedangkan jika nilai $\alpha$ bernilai 1 , artinya $100 \%$ bunyi yang datang dapat diserap oleh bahan yang digunakan sebagai papan akustik (Lee dan Joo, 2003 dalam Kusuma, 2012). Berdasarkan dari uraian diatas maka penulis melakukan penelitian yang berjudul "Pengujian Kerapatan, Kadar Air dan Koefisien Absorbsi Papan Akustik Berbahan Dasar Daun Pandan Duri (Pandanus tectorius)".

\section{METODE PENELITIAN}

Penelitian dilakukan pada bulan Desember 2018 hingga Juli 2019, di Laboratorium Pengolahan dan Pemanfaatan Hasil Hutan Fakultas Kehutanan UNHAS Makassar (Pembuatan Sampel) dan Laboratorium Optik Fisika Fakultas Sains dan Teknologi UIN Alauddin Makassar. Alat dan bahan yang digunakan yaitu neraca digital, cetakan, stik besi, gelas plastik, pengaduk, lesung, blender, pisau, gunting, wadah (baskom), hotpress, aluminium foil, plat seng, mesin pemotong papan, sound level meter (SLM), speaker, laptop dengan aplikasi software true tone generator, jangka sorong, mikrometer sekrup, neraca digital, oven, daun pandan duri, resin poliester, katalis, kaos tangan karet, masker, serta tissue.

Pengambilan data nilai koefisien absorbsi dilakukan didalam sebuah ruang kaca yang berukuran $100 \times 25 \times 25 \mathrm{~cm}$, 


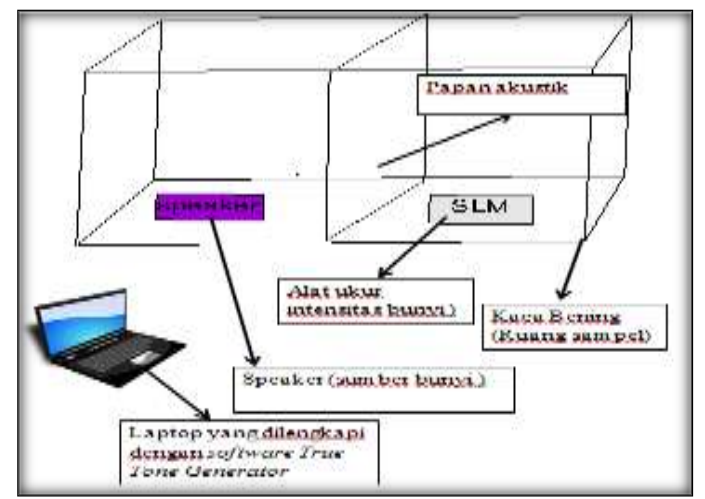

Gambar 1. Rangkaian ruang pengujian

Pengambilan data dilakukan dengan cara menyusun peralatan seperti gambar diatas, dimana sound level meter diletakkan sebelum papan akustik dan speaker yang terhubung dengan sebuah laptop denga aplikasi test tone generator diletakkan setelah papan akustik. Frekuensi yang digunakan pada penelitian ini yaitu $125 \mathrm{~Hz}, 250 \mathrm{~Hz}, 500 \mathrm{~Hz}, 1000 \mathrm{~Hz}, 2000 \mathrm{~Hz}$ dan $4000 \mathrm{~Hz}$, dengan ketebalan material papan akustik yaitu $0,7 \mathrm{~cm}, 1,0 \mathrm{~cm}, 1,2 \mathrm{~cm}$ dan 1,5 $\mathrm{cm}$. Sound level meter (SLM) pada penelitian ini berfungsi untuk mengetahui intensitas awal (sebelum material akustik dipasang) dan intensitas akhir (setelah material akustik dipasang). Menurut Sears, dkk (1962), untuk menentukan nilai koefisien absorbsi suatu permukaan digunakan persamaan berikut:

$$
\propto=\frac{\ln I_{0}-\ln I}{x}
$$

keterangan:

$I_{0}=$ intensitas bunyi sebelum melewati medium penyerap $(\mathrm{dB})$

$\mathrm{I}=$ intensitas bunyi setelah melewati medium penyerap $(\mathrm{dB})$

$\mathrm{x}=$ ketebalan medium penyerap $(\mathrm{cm})$

$\alpha=$ koefisien serapan bunyi

Pengujian kerapatan dilakukan untuk mengetahui ukuran kekompakan suatu material. Pengujian kerapatan terhadap material akustik dilakukan dengan cara mengukur massa material menggunakan neraca digital, kemudian mengukur dimensi panjang dan lebar menggunakan jangka sorong serta mengukur tinggi material menggunakan mikrometer sekrup. Persamaan kerapatan yang digunakan menurut Douglas (2001) yaitu:

$$
\rho=\frac{m}{V}
$$

keterangan:

$$
\begin{aligned}
& \rho=\text { kerapatan }\left(\mathrm{g} / \mathrm{cm}^{3}\right) \\
& \mathrm{m}=\text { massa benda }(\mathrm{gr}) \\
& V=\text { volume benda }\left(\mathrm{cm}^{3}\right)
\end{aligned}
$$

Nilai kerapatan suatu papan partikel menurut Maloney (1993), terbagi menjadi tiga golongan yaitu, papan partikel berkerapatan rendah $(<0,4 \mathrm{gr} / \mathrm{cm} 3)$, papan partikel berkerapatan sedang $(0,4 \mathrm{gr} / \mathrm{cm} 3-0,8 \mathrm{gr} / \mathrm{cm} 3)$ serta papan partikel berkerapan tinggi (>0,8 $\mathrm{gr} / \mathrm{cm} 3)$. 
Pengujian nilai kadar air suatu material dilakukan dengan menimbang atau mengukur massa material sebelum dioven (kering udara) dan mengukur masssa material setelah dioven (kering oven) menggunkan neraca digital. Adapun persamaan yang digunakan untuk mengetahui nilai kadar air suatu material berdasarkan SNI 03-2105-2006 yaitu:

$$
K a=\frac{K u-K o}{K o} \times 100 \%
$$

keterangan:

$$
\begin{aligned}
& \mathrm{Ka}=\text { kadar air } \\
& \mathrm{Ku}=\text { berat awal ( } \mathrm{gr}) \\
& \mathrm{Ko}=\text { berat akhir (setelah dikeringkan dengan oven) (gr) }
\end{aligned}
$$

Nilai kadar air dari semua jenis papan partikel yang dibuat haruslah memenuhi standar SNI 03-2105-2006 untuk parameter kadar air yang ditetapkan yaitu antara 5-13 $(<14) \%$. Semakin tinggi kadar air bahan baku menyebabkan tingginya kadar air papan, hal ini dikarenakan uap air bahan baku terperangkap saat proses pengepresan. Dalam pembuatan papan, kadar air partikel harus berkisar antara $2-5 \%$ sehingga jika ditambah dengan perekat maka kadar air partikel akan meningkat hingga 4-6\% (Haygreen \& Bowyer, 1996).

\section{HASIL DAN PEMBAHASAN}

Penelitian ini dilakukan dengan dua tahapan yaitu tahap pembuatan material akustik dan tahap pengujian material akustik yang meliputi tiga hal yaitu pengujian koefisien absorbsi, pengujian kerapatan papan dan pengujian kadar air. Pada penelitiaan ini digunakan dua jenis sampel bahan yaitu sampel tumbuk dan sampel blender dengan variasi ketebalan $0.7 \mathrm{~cm}, 1.0 \mathrm{~cm}, 1.2 \mathrm{~cm}$ dan $1.5 \mathrm{~cm}$, serta frekuensi yang digunakan yaitu $125 \mathrm{~Hz}, 250 \mathrm{~Hz}, 500 \mathrm{~Hz}, 1000 \mathrm{~Hz}, 2000 \mathrm{~Hz}$ dan $4000 \mathrm{~Hz}$. Pengukuran nilai koefisien absorbsi dilakukan dengan mengukur nilai intensitas bunyi, pengukuran menggunakan alat Sound Level Meter (SLM) yang memiliki fungsi untuk mengukur tingkat intensitas bunyi, setelah mengetahui nilai intensitas awal $\left(I_{0}\right)$ dan nilai intensitas akhir yaitu setelah melalui material akustik(I).

\section{Pengujian Koefisien Absorbsi}

Pengujian koefisien absorbsi yaitu pengujian yang dilakukan untuk mengetahui seberapa bagus suatu material dalam menyerap bunyi yang mengenai material tersebut yang memenuhi standar SNI 03-2105-2006. Nilai koefisien absorbsi suatu material sangat dipengaruhi oleh beberapa faktor yaitu ketebalan material, kerapatan serta porositas material tersebut. Berikut grafik hasil penelitian nilai koefisien absorbsi pada material dari bahan daun pandan duri dengan variasi ketebalan dan frekuensi yang digunakan. 


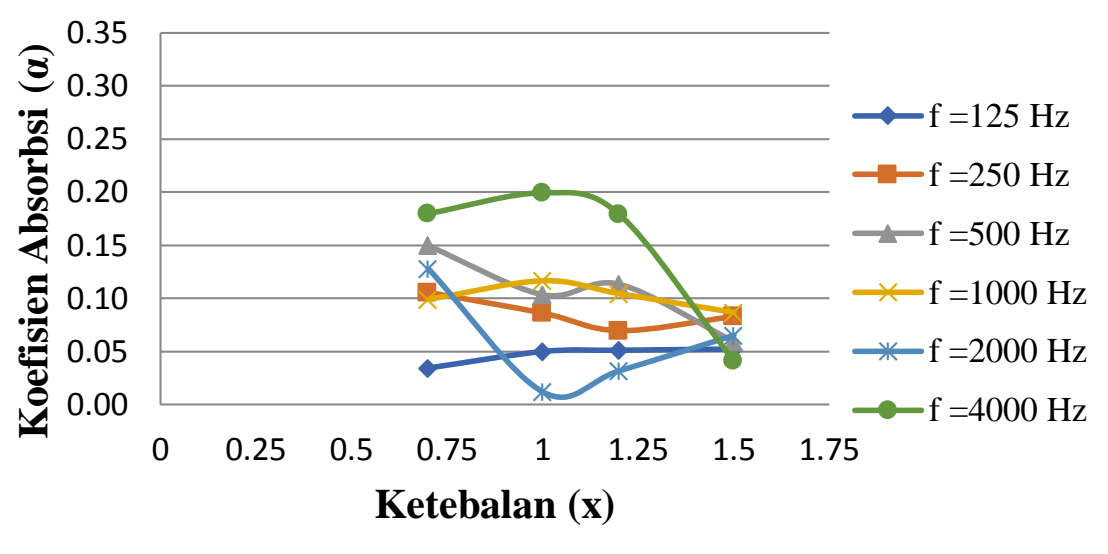

Grafik 2. Hubungan koefisien absorbsi terhadap ketebalan dengan variasi frekuensi sampel blender

Berdasarkan teori dari persamaan terhadap koefisien absorbsi, hubungan antara ketebalan dan koefisien absorbsi berbanding terbalik, yaitu dimana semakin tebal suatu material akustik makan nilai koefisien absorbsinya akan semakin kecil. Dari grafik diatas dapat dinyatakan bahwa terjadi fluktuasi pada beberapa frekuensi. Grafik yang menyimpang atau tidak sesuai dengan teori, kemungkinan disebabkan karena pada proses pengambilan data banyak gangguan-gangguan dilingkungan sekitar seperti suara kendaraan, suara bising dari tetangga dan sebagainya dimana Sound Level Meter yang juga sangat sensitif terhadap bunyi disekeliling sehingga sangat berpengaruh terhadap intensitas yang terbaca pada SLM. Material daun pandan duri untuk blender menghasilkan nilai koefisien serap bunyi yang baik pada frekuensi $4000 \mathrm{~Hz}$ dan pada ketebalan $1.0 \mathrm{~cm}$.

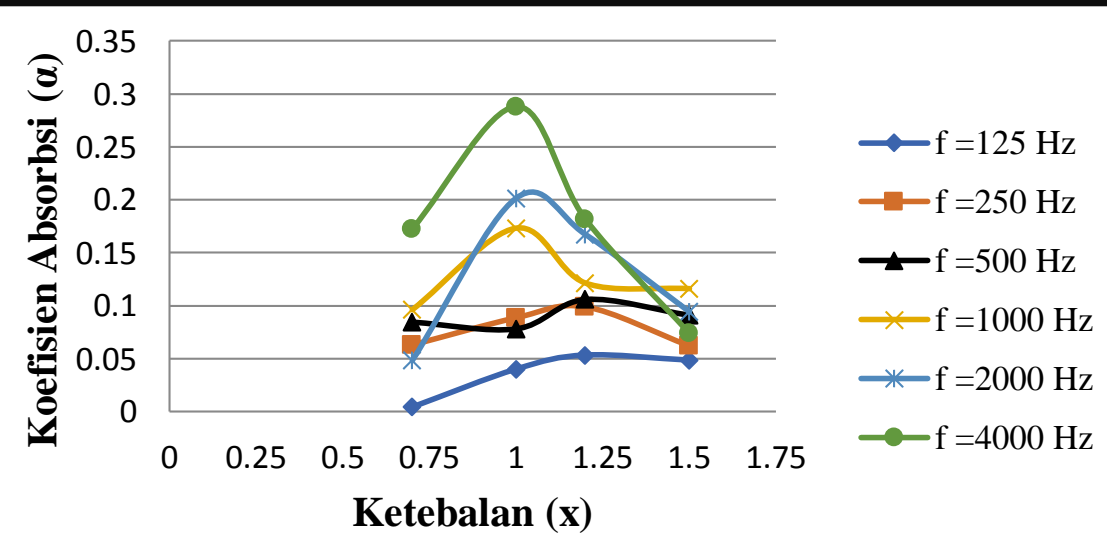

Grafik 3. Hubungan koefisien absorbsi terhadap ketebalan dengan variasi frekuensi sampel tumbuk

Berdasarkan pada hasil penelitian maka bahan daun pandan duri digolongkan sebagai bahan penyerap berpori, menurut Doelle (1985) suatu bahan penyerap bunyi yang digunakan sebagai pengendali bunyi pada ruang- 
ruang yang bising jika tergolong sebagai material berpori-pori maka penyerapan bunyi material tersebut lebih efisien pada frekuensi tinggi.

Daun pandan duri merupakan bahan yang tergolong sebagai penyerap berpori, dimana berdasarkan dari grafik diatas terlihat bahwa nilai koefisien absorbsi yang baik yaitu pada frekuensi tinggi. Terjadi penyimpangan pada ketebalan 0,7 cm dimana menurut penelitian yang dilakukan oleh Akbar (2017) dimana nilai koefisien absorbsinya menurun disebabkan karena frekuensi yang mengenai bidang atau suatu material pada saat itu amplitudo gelombang bukan berada pada posisi puncak. Pada grafik tumbuk di atas nilai yang menyimpang dari teori dapat disebabkan karena pada saat pengambilan data banyaknya suara-suara pengganggu di sekitar ruang pengujian yang menyebabkan grafik tersebut tidak sesuai dengan teori yang seharusnya.

\section{Pengujian Kerapatan}

Kerapatan suatu material akustik yang baik digunakan yaitu material yang tergolong dalam kerapatan sedang, karena jika suatu material akustik memiliki kerapatan rendah maka akan menyebabkan partikel-partikel menjadi sangat renggang dan tidak baik dalam meyerab bunyi sedangakn untuk kerpatan material yang berfrekuensi tinggi juga tidak baik digunakan karena material tersebut hanya akan menjadi material pemantul dimana tidak akan ada bunyi yang diserap (Mediastika. 2009).

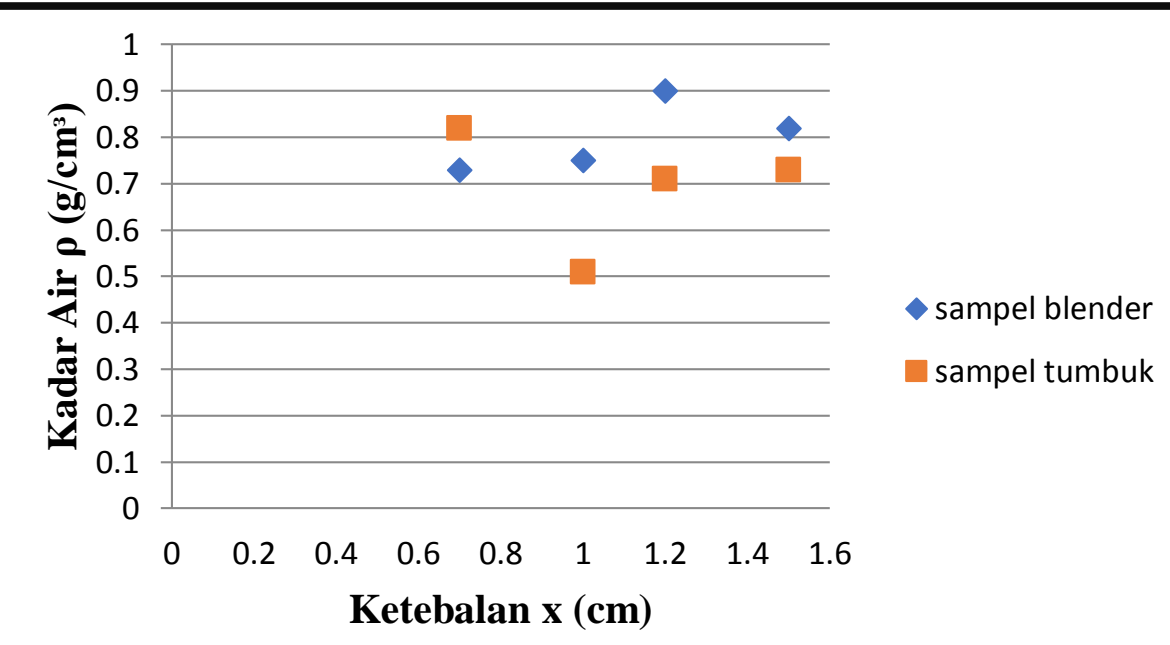

Grafik 4. Kerapatan papan akustik dengan ukuran sampel berbeda

Nilai kerapatan untuk sampel blender lebih tinggi dibandingkan sampel tumbuk, kecuali untuk ketebalan $0,7 \mathrm{~cm}$ dimana sampel tumbuk lebih tinggi dari material blender, hal ini kemungkinan disebabkan pada saat pencetakan perekat yang diberikan pada material tersebut sedikit lebih banyak sehingga menyebabkan kerapatannya ikut meningkat. Nilai kerapatan untuk sampel tumbuk yaitu $0,510 \mathrm{gr} / \mathrm{cm} 3-0,820 \mathrm{gr} / \mathrm{cm} 3$ sedangkan untuk sampel blender nilai kerapatan yang dihasilkan yaitu berkisar antara 0,730 gr/cm3-0,903 gr/cm3. Sampel dengan blender memiliki kerapatan yang lebih tinggi disebabkan karena partikel-partikel pada material tersebut saling berikatan dengan baik sehingga ruang kosong yang terdapat pada material tersebut semakin kecil yang menyebabkan kerapatan yang dihasilkan akan meningkat. 


\section{Pengujian Kadar Air}

Pengujian kadar air dilakukan dengan cara mengukur massa sampel dalam keadaan kering udara setelah itu memasukkan sampel ke dalam oven selama 6 jam dengan suhu 105oC, selanjutnya mengukur kembali massa sampel dalam keadaan kering oven.

Nilai kadar air suatu material sangat dipengaruhi oleh banyaknya komposisi perekat yang digunakan, dimana semakin banyak perekat yang digunakan dan semakin meningkatnya suhu akan mengakibatkan ikatan antar partikel dalam material akan semakin kuat sehingga sebagian air yang terkandung didalam material akan terdorong keluar pada saat proses pengempaan (Widarmana, 1997).

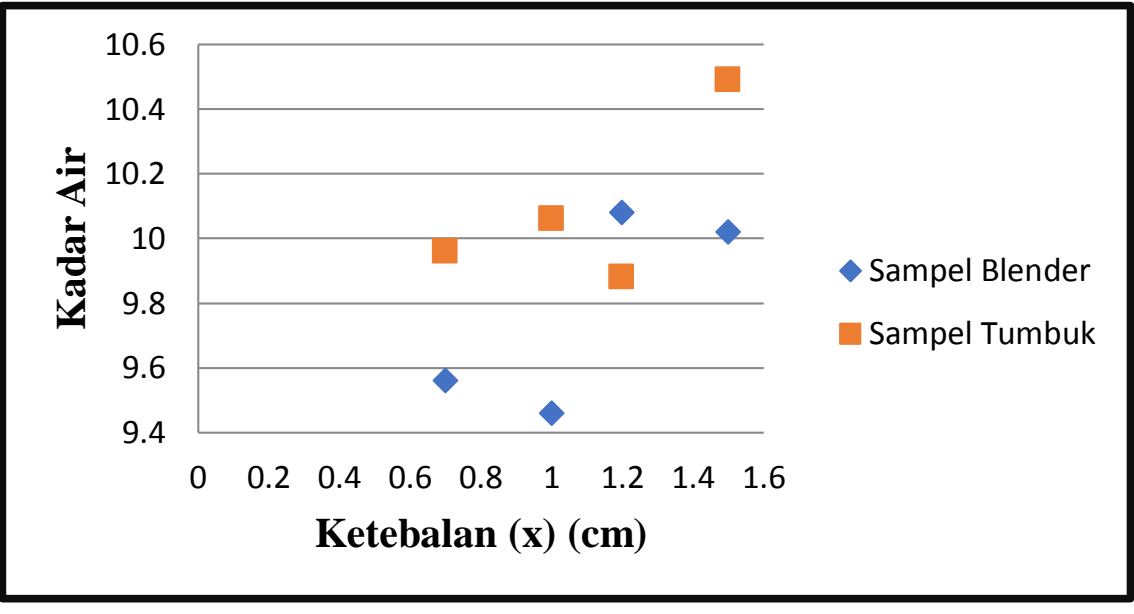

Grafik 5. Kadar air papan akustik dengan ukuran sampel berbeda

Sampel dengan nilai kadar air sangat tinggi yaitu pada sampel tumbuk dan pada ketebalan $1,5 \mathrm{~cm}$ hal ini dapat disebabkan karena pada sampel tumbuk kandungan air pada bahan baku material tidak banyak melepaskan air saat proses penjemuran maupun saat proses penghancuran, berbeda dengan sampel blender dimana bahan baku material ditumbuk sebelum dikeringkan dan saat proses penumbukan sebagian besar kandungan air dari bahan baku tersebut telah terlepas.

\section{SIMPULAN}

Berdasarkan hasil penelitian maka dapat disimpulkan bahwa sifat fisis untuk papan akustik berbahan dasar daun pandan duri khususnya untuk kerapatan dan nilai kadar air memenuhi standar SNI 03-2105-2006. Untuk pengujian kadar air pada sampel tumbuk yaitu sekitar 9,88\%- $10.49 \%$ dan untuk sampel blender yaitu sekitar 9,46\%-10,2\% sedangkan untuk pengujian kerapatan papan akustik untuk sampel blender didapatkan nilai kisaran 0,730 $\mathrm{gr} / \mathrm{cm}^{3}-0,903 \mathrm{gr} / \mathrm{cm}^{3}$ dan untuk sampel tumbuk didapatkan nilai yaitu 0,510 $\mathrm{gr} / \mathrm{cm}^{3}-0,820 \mathrm{gr} / \mathrm{cm}^{3}$.

Nilai koefisien absorbsi untuk sampel tumbuk yaitu berkisar 0,005-0,288 dimana koefisien tertinggi berada pada frekuensi $4000 \mathrm{~Hz}$ dan untuk koefisien terendah yaitu pada frekuensi $125 \mathrm{~Hz}$, sedangkan untuk sampel blender nilai koefisien berkisar antara 0.012-0,199 dimana koefisien tertinggi berada pada frekuensi $4000 \mathrm{~Hz}$ dan koefisien terendah berada pada frekuensi $2000 \mathrm{~Hz}$. Pengaruh variasi ketebalan terhadap koefisien absorbsi yaitu berbanding 
terbalik, semakin tinggi ketebalan suatu material maka akan smakin rendah nilai koefisien absorbsinya, sedangkan pengaruh frekuensi terhadap koefisieen absorbsi yaitu semakin tinggi frekuensi yang diberikan maka nilai koefissien absorbsinya akan semakin tinggi pula.

\section{DAFTAR PUSTAKA}

Akbar, Muhammad. 2017. Karakterisasi Papan Akustik Dari Limbah Kulit Jagung Dengan Perekat Lem Fox. Makassar: Fakultas Sains dan Teknologi UINAM.S

Buku Ensiklopedia Online. http://pandan.gigafarm.web.id/ind/1152-1046/Pandan 94407 trianandra_pandan-gigafarm.html. Diakses 02 Februari 2019.

Douglas C. Giancoli. 2001. Fisika Edisi ke Lima Jilid 1. Jakarta: Erlangga.

Gabriel, J.F. 1996. Fisika Kedokteran. Jakarta: EGC.

Haygreen JG, Bowyer JL. 1996. Hasil Hutan dan IImu Kayu. Suatu Pengantar. Hadikusumo SA, penerjemah; Prawirohatmodjo S, editor. Yogyakarta: Gajah Mada University Press. Terjemahan dari: Forest Product and Wood Science, and Introduction.

Karlinasari, Lina, dkk. 2011. Sifat Penyerapan Dan Isolasi Suara Papan Wol Berkerapatan Sedang-Tinggi Dari Beberapa Kayu Cepat Tumbuh. Jurnal Ilmu dan Teknologi Hasil Hutan 4(1): 8-13 (2011).

Kusuma, Elang Sandhi. 2012. Pengujian Panel Akustik Papan Partikel Kayu Sengon (Paraserianthes falcataria). Bogor: Departemen Hasil Hutan, Fakultas Kehutanan, IPB.

Maloney, T.M. 1993. Modern Particleboard and Dry Process Fiberboard Manufactoring. Miller Freeman Inc, New York.

Mediastika, Christina eviutami. 2005. Akustika Bangunan:Prinsip-prinsip dan Penerapannya di Indonesia. Jakarta: Erlangga.

Sears, dkk. 1962. Fisika Untuk Universitas I Mekanika Panas Bunyi, terjemah oleh Soedarjana dan Achmad Amir. Jakarta: Bina Cipta

Setiawan, Agung. 2017. Prediksi Tingkat Kebisingan Lalu Lintas Heterogen Berbasis Sistem Informasi Geografis. Makassar: Departeman Teknik Lingkungan Fakultas Teknik UNHAS.

Standard Nasional Indonesia. 2006. Papan Partikel (SNI 03-2105-2006). Badan Standarisasi Nasional.

Suhaemin, dkk. 2013. Koefisien Serap Bunyi Papan Partikel Dari Bahan Serbuk Kayu Kelapa. Palopo. Jurusan Fisika FMIPA UNSRAT.

Ulfayanti, Andi. 2016. Studi Karakteristik Material Akustik Berbahan Sandwich Kertas Koran Dan Gabus Dengan Perekat Sagu. Makassar: Fakultas Sains dan Teknologi UINAM.

Widarmana S. 1977. Panil-Panil Berasal Dari Kayu Sebagai Bahan Bangunan. Bogor. Proceeding Seminar Persaki: Pengurus Pusat Persaki. 